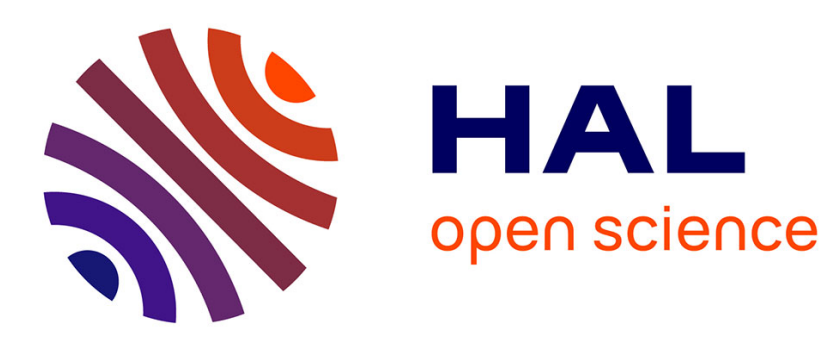

\title{
Removal of volatile organic compounds by heterogeneous ozonation on microporous synthetic alumina silicate
}

\author{
Nicolas Brodu, Hicham Zaitan, Marie-Hélène Manero, Jean-Stéphane Pic
}

\section{To cite this version:}

Nicolas Brodu, Hicham Zaitan, Marie-Hélène Manero, Jean-Stéphane Pic. Removal of volatile organic compounds by heterogeneous ozonation on microporous synthetic alumina silicate. Water Science and Technology, 2012, vol. 66 (9), pp. 2020-2026. 10.2166/wst.2012.385 . hal-00926358

\section{HAL Id: hal-00926358 https://hal.science/hal-00926358}

Submitted on 9 Jan 2014

HAL is a multi-disciplinary open access archive for the deposit and dissemination of scientific research documents, whether they are published or not. The documents may come from teaching and research institutions in France or abroad, or from public or private research centers.
L'archive ouverte pluridisciplinaire HAL, est destinée au dépôt et à la diffusion de documents scientifiques de niveau recherche, publiés ou non, émanant des établissements d'enseignement et de recherche français ou étrangers, des laboratoires publics ou privés. 


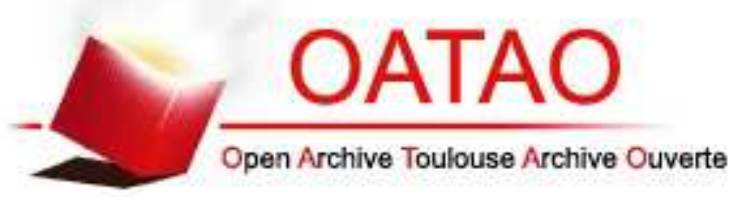

\section{Open Archive TOULOUSE Archive Ouverte (OATAO)}

OATAO is an open access repository that collects the work of Toulouse researchers and makes it freely available over the web where possible.

This is an author-deposited version published in : http://oatao.univ-toulouse.fr/ Eprints ID : 10060

To link to this article : DOI:10.2166/wst.2012.385

URL : http://dx.doi.org/10.2166/wst.2012.385

\section{To cite this version :}

Brodu, Nicolas and Zaitan, Hicham and Manero, Marie-Hélène and Pic, Jean-Stéphane Removal of volatile organic compounds by heterogeneous ozonation on microporous synthetic alumina silicate. (2012) Water Science and Technology, vol. 66 ( $\mathrm{n}^{\circ}$ 9). pp. 2020-2026. ISSN 0273-1223

Any correspondance concerning this service should be sent to the repository administrator: staff-oatao@ listes-diff.inp-toulouse.fr 


\title{
Removal of volatile organic compounds by heterogeneous ozonation on microporous synthetic alumina silicate
}

\author{
Nicolas Brodu, Hicham Zaitan, Marie-Hélène Manero \\ and Jean-Stéphane Pic
}

\begin{abstract}
A hybrid process combining adsorption and ozonation was examined as an alternative treatment for odorous volatile organic compounds (VOCS). Methyl ethyl ketone (MEK) was chosen to study the influence of operating parameters. Two synthetic aluminosilicates (faujasite-Y and ZSM-5) were tested for adsorption and reactivity with ozone. The adsorption equilibrium measurement on both adsorbents showed that adsorption performance depends on temperature but is not sensitive to relative humidity, due to the hydrophobic properties of the materials. Adsorbed vocs were oxidized at low temperature when ozonated flow was sent to the reactor. Regeneration of the fixed bed was achieved at the same time, releasing mainly $\mathrm{CO}_{2}$ and $\mathrm{H}_{2} \mathrm{O}$. Intermediates of oxidation, such as 2,3-butanedione and acetic acid, were identified, leading to incomplete mineralization. The influence of concentration and humidity are discussed. Four successive cycles were tested: after the first adsorption/ozonation cycle, the adsorption efficiency was not affected during subsequent cycles. These results show that the same sample of adsorbent can be used in the treatment process for a long time. Ozonation regeneration is a promising process for VOC removal.
\end{abstract}

Key words | adsorption, alumina silicate, odours, ozonation, volatile organic compounds

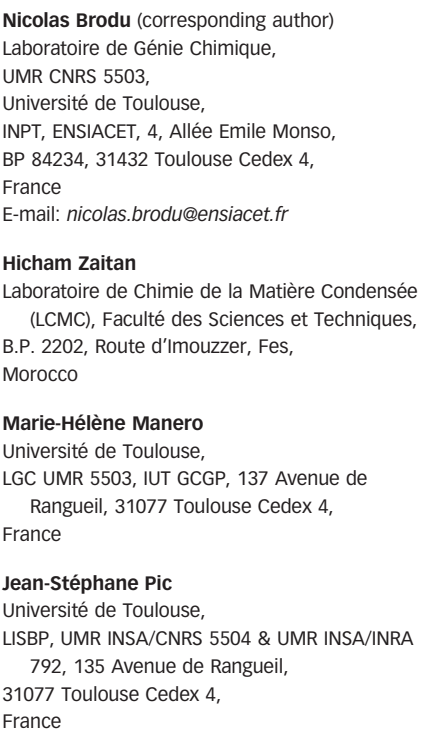

\section{INTRODUCTION}

Among many techniques available for controlling volatile organic compound (VOC) emissions, adsorption on activated carbon (AC) has been found to be effective at low concentration levels (Zhao et al. I998). However, the regeneration of AC remains a problem because the regeneration process is slow, expensive and may cause irreversible damages to AC (Alvarez et al. 2004). The crystalline and mineral structures of aluminosilicate adsorbents give them strong thermal and chemical stability, and new ways of regeneration, such as oxidation with powerful oxidants like ozone (Sagehashi et al. 2005; Monneyron et al. 2007), have been explored recently. Oxidation using ozone, and supported by catalysts, has already been used for the treatment of air polluted with hazardous compounds (Konova et al. 2006; Einaga \& Ogata 2009). Very few studies focused on the coupling of ozone and aluminosilicates to remove VOCs (Monneyron et al. 2007; Kwong et al. 2008; Valdes et al. 2009; Einaga et al. 20I0). In the present work, methyl ethyl ketone (MEK; butan-2-one) was chosen as a common odorous pollutant. This compound was also chosen for its very weak reactivity with ozone in the gaseous phase.

\section{METHODS}

\section{Adsorbents and adsorbate}

Two types of aluminosilicate were used, supplied by TOSOH Corp. in the form of pellets: a de-aluminated faujasite Y (Fau-Y) and a silicalite ZSM-5. The main characteristics of the adsorbents are given in Table 1 . Prior to experimentation, the adsorbents were heated in a drying oven at $500 \mathrm{~K}$ for $24 \mathrm{~h}$ and kept in a desiccator. The VOC used in this study was MEK (purity >99\%), purchased from Aldrich. 


\begin{tabular}{lll} 
Table $\mathbf{1} \mid$ Characteristics of the adsorbents & & \\
Type (symbol) & Faujasite & ZsM-5 \\
\hline Crystalline framework & $\alpha$-cages & Interconnected channels \\
Pore diameter $(\AA)$ & 7.4 (aperture) - 13(cage Ø) & $(5.7 \times 5.1)$ and 5.4 \\
$\mathrm{SiO}_{2} / \mathrm{Al}_{2} \mathrm{O}_{3}\left(\mathrm{~mol} \mathrm{~mol}^{-1}\right)$ & 360 & 1,880 \\
$\mathrm{Active}^{2}$ porous volume $\left(\mathrm{cm}^{3} \mathrm{~g}^{-1}\right)$ & 0.24 & 0.18 \\
$\mathrm{BET}^{\mathrm{a}}$ surface area $\left(\mathrm{m}^{2} \mathrm{~g}^{-1}\right)$ & 650 & 300 \\
$\mathrm{Granular}$ diameter $(\mathrm{mm})$ & 3 & 1.5
\end{tabular}

aBrunauer-Emmett-Teller.

\section{Laboratory-scale pilot}

Adsorption isotherms were performed using a static volumetric apparatus, described in a previous study (Brosillon et al. 200I). Adsorbed quantities were normalized for pure zeolite material, assuming that the inert clay binder mass does not participate in the adsorption phenomena. The experimental fixed bed is shown in Figure 1. It is composed of a polluted air generator, an ozonated air generator (5LO Trailigaz model) and a glass reactor (internal diameter (ID): $8 \mathrm{~cm}$, length: $20 \mathrm{~cm}$ ) in which adsorbents are introduced (from $100 \mathrm{~g}$ to $200 \mathrm{~g}$ ). Experimental conditions were: air flow rate $5 \mathrm{~m}^{3} \mathrm{~h}^{-1}$, VOC concentration $1.35 \mathrm{~g} \mathrm{~m}^{-3}$ and ozonated air flow fixed between 0.1 and $0.25 \mathrm{~m}^{3} \mathrm{~h}^{-1}$. Ozone concentration was $18 \mathrm{~g} \mathrm{~m}^{-3}$. The adsorption and ozonation occurred at room temperature $\left(24^{\circ} \mathrm{C} \pm 2{ }^{\circ} \mathrm{C}\right)$.

On-line gas analysis was performed using a Varian 3800 gas chromatograph (GC) equipped with flame ionization (FID) and thermal conductivity (TCD) detectors. VOCs were analysed with a CP-SIL 8 capillary column $(30 \mathrm{~m} \times$ $0.53 \mathrm{~mm}$ ID) with a $1.0 \mu \mathrm{m}$ film thickness, and $\mathrm{CO}_{2}$ with a Hayesep Q 60/80 column $(1 \mathrm{~m} \times 3 \mathrm{~mm})$. Ozone concentration was determined by a UV BMT 964 Ozone Analyzer.

\section{RESULTS AND DISCUSSION}

\section{Adsorption equilibrium isotherms of MEK}

Adsorption isotherms were determined for both adsorbents at a low partial relative pressure range, corresponding to $P / P_{0} \leq 0.1$ or $C \leq 35 \mathrm{~g} \mathrm{~m}^{-3}$. As previous research seemed to prove that temperature could enhance adsorption capacity of aluminosilicates (Wang et al. 2006), the influence of temperature (T) on isotherms was investigated. Furthermore, the influence of moisture (relative humidity) was studied on the adsorption capacity of these adsorbents.

The experimental adsorption isotherms are presented in Figure 2(a) (influence of T) and 2(b) (influence of relative humidity; RH). A sharp increase in capacity is observed at low partial pressures for ZSM-5, corresponding to micropore filling, followed by a flat plateau region at relatively high partial pressures indicating good adsorption affinity. The isotherm curves are of type I of the IUPAC classification (Sing et al. 1985) and can be modelled by the Langmuir equation as expected for this kind of microporous adsorbent (Monneyron et al. 2003). For Fau-Y adsorption, a weaker increase can be observed at low partial pressures but stabilization is found at higher values than for ZSM-5. This result is explained by a greater porous volume for Fau-Y than for ZSM-5: $0.24 \mathrm{~cm}^{3} \mathrm{~g}^{-1}$ versus $0.18 \mathrm{~cm}^{3} \mathrm{~g}^{-1}$.

The increase in temperature of adsorption decreases the quantity of MEK adsorbed on ZSM-5 and Fau-Y. Using the assumption that the adsorbed phase is comparable with a liquid state, micropore filling was calculated at this plateau region. The volumes of MEK adsorbed on ZSM- 5 at this plateau are $0.148 \mathrm{~cm}^{3} \mathrm{~g}^{-1}$ at $298 \mathrm{~K}$ and $0.141 \mathrm{~cm}^{3} \mathrm{~g}^{-1}$ at $333 \mathrm{~K}$, corresponding to filling rates of $82 \%$ and $78 \%$, respectively. On Fau-Y, the filling rate of MEK is $87 \%$ (298 K) and 51\% $(333 \mathrm{~K})$, indicating a higher loss of adsorption capacity with temperature. These differences can be explained by the pore structure and pore diameter. The pores of ZSM-5 $(5.5 \AA)$ are narrower than Fau-Y (7.4 ̊). The MEK molecules with a kinetic diameter of $5.2 \AA$ interact strongly with the channel walls of ZSM-5, whereas this interaction is much smaller in large pore aluminosilicates, such as Fau-Y (Meininghaus et al. 200o).

Regarding the influence of humidity, results presented in Figure 2(b) showed that the adsorption capacity was not significantly affected by moisture content. The hydrophobicity of both materials is proven. 
(a)

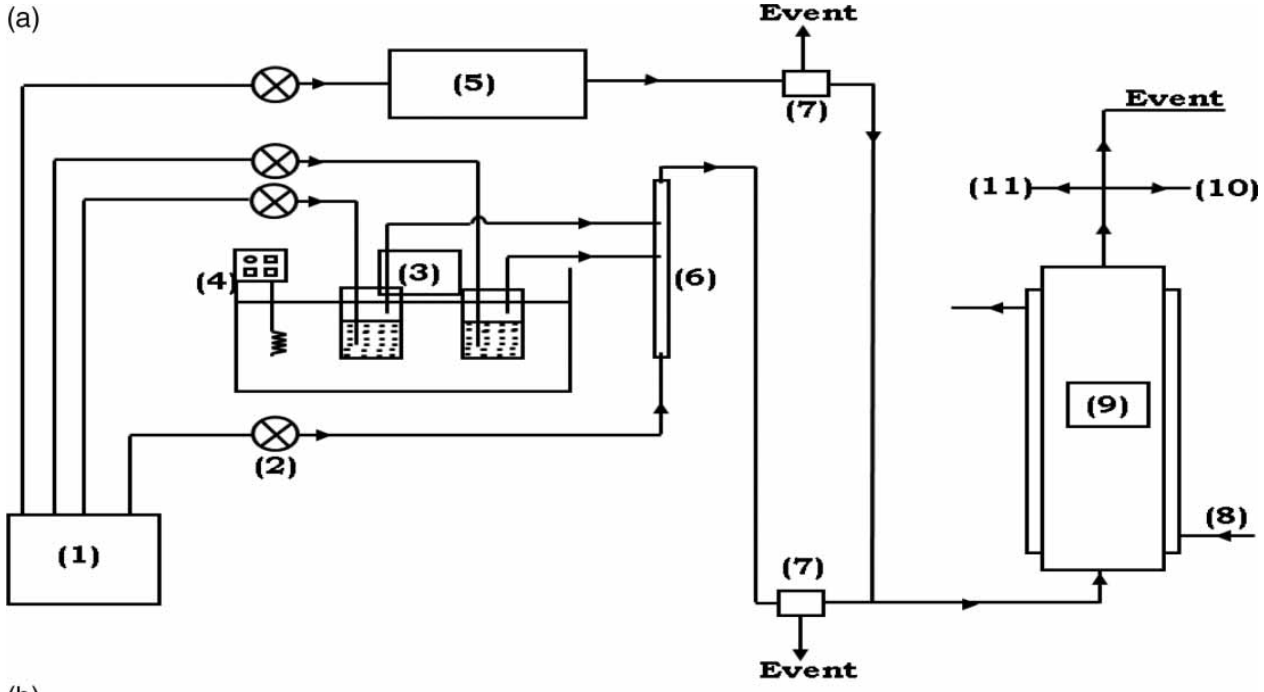

(b)

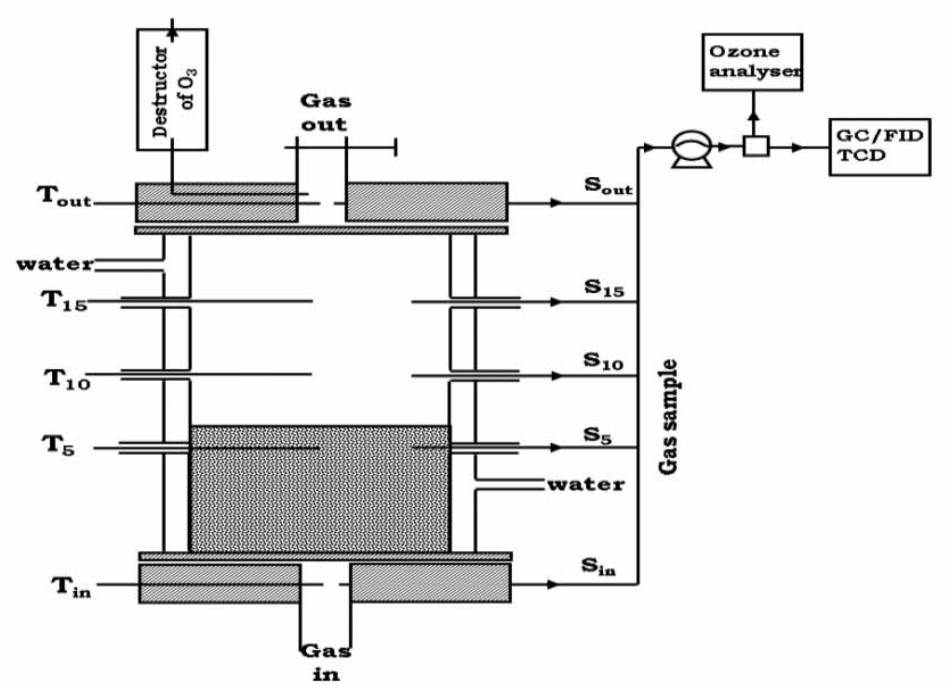

Figure 1 | (a) Scheme illustration for the experimental set-up of adsorption/ozonation. (1) air supply; (2) mass flow controller; (3) saturators; (4) thermostatic bath; (5) ozone generator; (6) mixing volume; (7) 3-way valve; (8) temperature control fluid; (9) reactor; (10) GC/FID/TCD and (11) ozone analyser; (b) Schematic diagram of the reactor designed for this application.

\section{The adsorption/ozonation treatment}

The treatment of polluted air was carried out in the laboratory-scale pilot by a sequential process: adsorption then ozonation. The typical course of an experiment is represented in Figure 3 for one cycle of adsorption/ozonation of MEK at room temperature.

\section{Adsorption step}

A classical breakthrough curve can be observed, with different curve shapes for the two adsorbents. The weak slope of the ZSM-5 curve can be explained by a wide mass transfer zone and a probable limitation by the internal resistance to transfer. The Fau-Y curve slope is slightly greater $\left(702 \mathrm{mg} \mathrm{m}^{-3} \mathrm{~h}^{-1}\right.$ versus $440 \mathrm{mg} \mathrm{m}^{-3} \mathrm{~h}^{-1}$ ) and the masstransfer zone is smaller, representative of better affinity with MEK.

The total amount of MEK adsorbed was obtained by integration of the breakthrough curve (hatched part on Figure 3). The results obtained for extrapolation to total saturation (0.103 and $0.043 \mathrm{~g} \mathrm{~g}^{-1}$ for ZSM-5 and Fau-Y respectively) are in quite good agreement with the static adsorption equilibrium. For a concentration of MEK of $1.35 \mathrm{~g} \mathrm{~m}^{-3}$, the adsorption capacity from isotherm experiments was $0.108 \mathrm{~g} \mathrm{~g}^{-1}$ for ZSM-5 and $0.062 \mathrm{~g} \mathrm{~g}^{-1}$ for Fau-Y. 

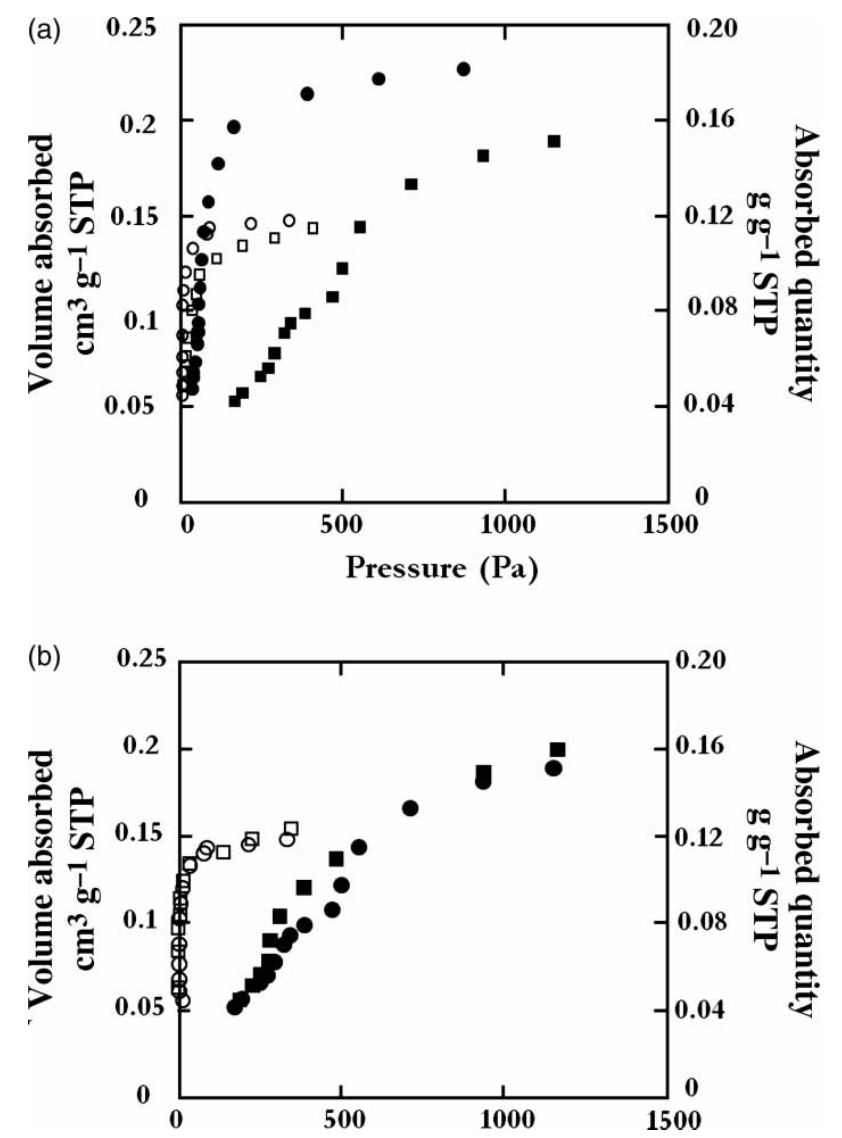

Figure 2 (a) Adsorption isotherms of MEK on two high-silica zeolites: influence of T: ZSM-5: O $298 \mathrm{~K} ; \square 333 \mathrm{~K}$; Fau-Y: • $298 \mathrm{~K}$; ・ $333 \mathrm{~K}$. (b) Adsorption isotherms of MEK on two high-silica zeolites: Influence of humidity (333 K): ZSM-5: O dry air $\square \mathrm{RH}=50 \%$; Fau-Y: • dry air; - $\mathrm{RH}=80 \%$.

\section{Ozonation step}

When a given partial saturation rate $\left(C_{\text {out }} / C_{\text {in }}=0.50\right)$ is reached, inlet polluted air is stopped and ozonated air $\left(18 \mathrm{~g} \mathrm{~m}^{-3}\right.$ under a flow of $0.25 \mathrm{~m}^{3} \mathrm{~h}^{-1}$ ) is sent through the reactor. A very high peak is observed (Figure 3) as soon as the ozonation begins, an indication of strong desorption of MEK. This thermal desorption is probably caused by the local heating induced by the oxidation. During this phase, very high temperature increases are seen (Figure 3B1 \& Figure 3B2): $\Delta T=106^{\circ} \mathrm{C}$ for ZSM- 5 and $145^{\circ} \mathrm{C}$ for Fau-Y.

The desorbed amount was determined by integration of the curve. The desorbed quantity is about $2.03 \mathrm{~g}$ of MEK for Fau-Y and $2.42 \mathrm{~g}$ for ZSM-5, which accounts for $26 \%$ and $15 \%$ of the initially adsorbed quantity for Fau-Y and ZSM-5 respectively. In an industrial situation, the adsorption step would be stopped before 50\% saturation, and the thermal desorbed VOCs would be less important and could be adsorbed in the bed zone free of adsorbate or could be recycled.

The regeneration of adsorption capacity was estimated by comparing the adsorbed quantities of MEK before and after each ozonation. The regeneration is very weak for ZSM-5 (22\%) whereas it is much stronger for Fau-Y (79\%). The structure of this channelled adsorbent may explain this result. If molecular ozone is not able to diffuse easily to meet adsorbed MEK, oxidation cannot take place, whereas the large cage structure of Fau-Y allows easy (a)

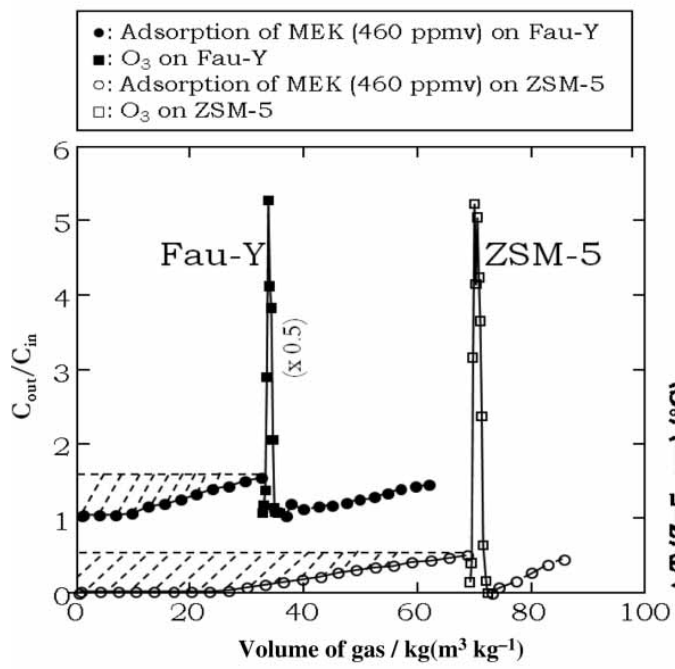

(b)
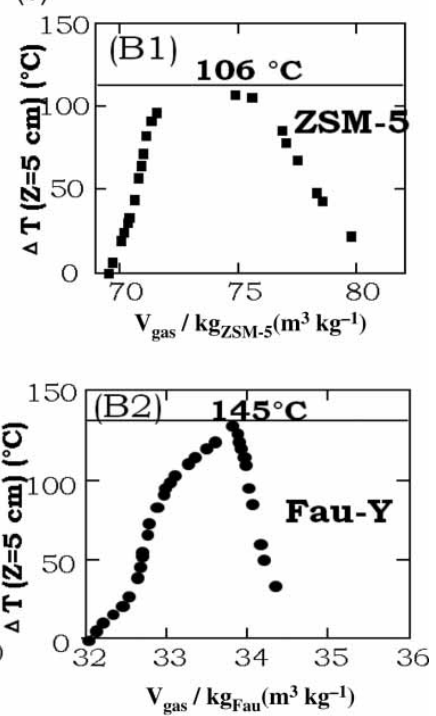

Figure 3 | (a) VOC concentration profiles during a discontinuous adsorption/ozonation cycle of MEK (1.35 $\mathrm{g} \mathrm{m}^{-3}$ ) on two adsorbents: ZSM-5 (202 g) and Fau-Y (205 g). (b) (B1) Temperature increase in ZSM-5 during ozonation. (B2) Temperature increase in Fau-Y during ozonation 
diffusion of ozone in the porous volume and an easy oxidation of the adsorbed component.

\section{Mass balance during ozonation step}

Using measurements of concentrations versus time the mass balance was determined for carbonated compounds and for ozone, and is presented in Table 2 for the experiment on ZSM-5. A comparison is made between the theoretical mineralization reaction (Equation (1)) and the real oxidation reaction due to stoichiometry coefficients:

$\mathrm{C}_{4} \mathrm{H}_{8} \mathrm{O}+11 / 3 \mathrm{O}_{3} \rightarrow 4 \mathrm{CO}_{2}+4 \mathrm{H}_{2} \mathrm{O}$

It can be seen that the mass balances of carbon and oxygen are incomplete and hence experimental and theoretical coefficients values are quite different. The lack of $\mathrm{CO}_{2}$ production and the weak ozone consumption are indicative of incomplete oxidation, with the formation of sub-products. These components are probably oxidation reaction intermediates, such as aldehydes, organic acids, ketones and alcohol. Indeed, the formation of other peaks was observed, showing the presence of sub-products such as acetone and ethanol. 2,3-butanedione and acetic acid were identified and their production was quantified (Table 2); traces of other sub-products were also detected.

\section{Successive cycles of adsorption/ozonation}

In order to evaluate the stability of the adsorbent during the cycle of adsorption and regeneration by $\mathrm{O}_{3}$, the reuse experiment was carried out. The operating conditions for the adsorption and ozonation steps were the same as described above. Tests of adsorption were carried out on a mass of $200 \mathrm{~g}$ of ZSM-5 and $205 \mathrm{~g}$ of Fau-Y, with a concentration of MEK of $1.35 \mathrm{~g} \mathrm{~m}^{-3}$ in the air for a total flow of $5 \mathrm{~m}^{3} \mathrm{~h}^{-1}$. The ozonation phase was carried out after each step of adsorption (50\% partial saturation) with a concentration of $\mathrm{O}_{3} /$ air of about $18 \mathrm{~g} \mathrm{Nm}^{-3}$ for a flow of $0.25 \mathrm{~m}^{3} \mathrm{~h}^{-1}$. Figures 4 and 5 show the changing MEK concentration on Fau-Y and ZSM-5.

The quantities of MEK adsorbed after the first phase of adsorption (cycle 1) are $15.4 \mathrm{~g}$ MEK on ZSM-5 and $7.18 \mathrm{~g}$ MEK on Fau-Y, confirming the better adsorption of ZSM-5 in the low concentration range. The breakthrough time of the second cycle of adsorption-ozonation is lower than the first, especially for ZSM- 5 , from $86 \mathrm{~min}$ to $8 \mathrm{~min}$ for ZSM- 5 and from 30 min to 18 min for Fau-Y. This seems to indicate a decrease of the adsorption capacities of the 


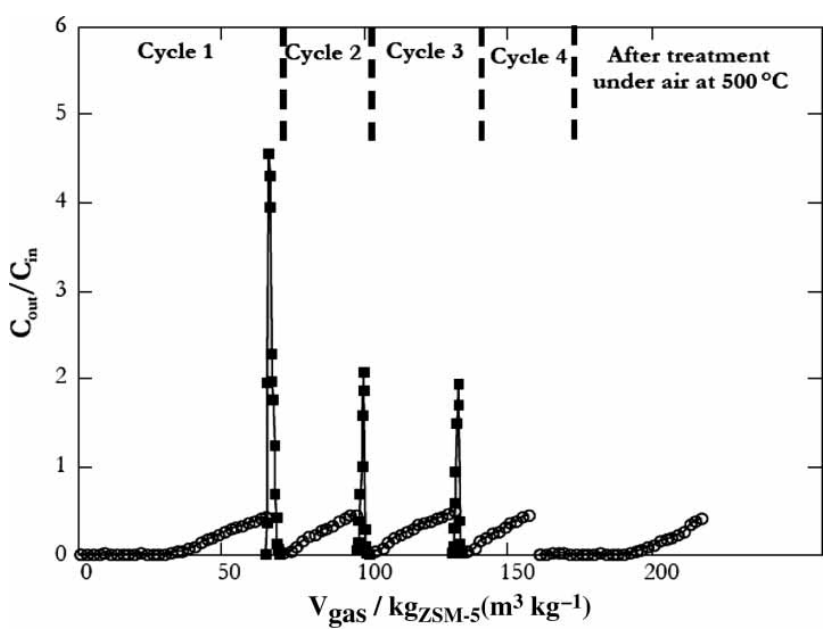

Figure 4 | Cyclic study of adsorption/ozonation of MEK on Fau-Y. O: adsorption of MEK $\left(1.35 \mathrm{~g} \mathrm{~m}^{-3}\right)$ on Fau-Y, $\mathbf{m}: \mathrm{O}_{3}$ on Fau-Y.

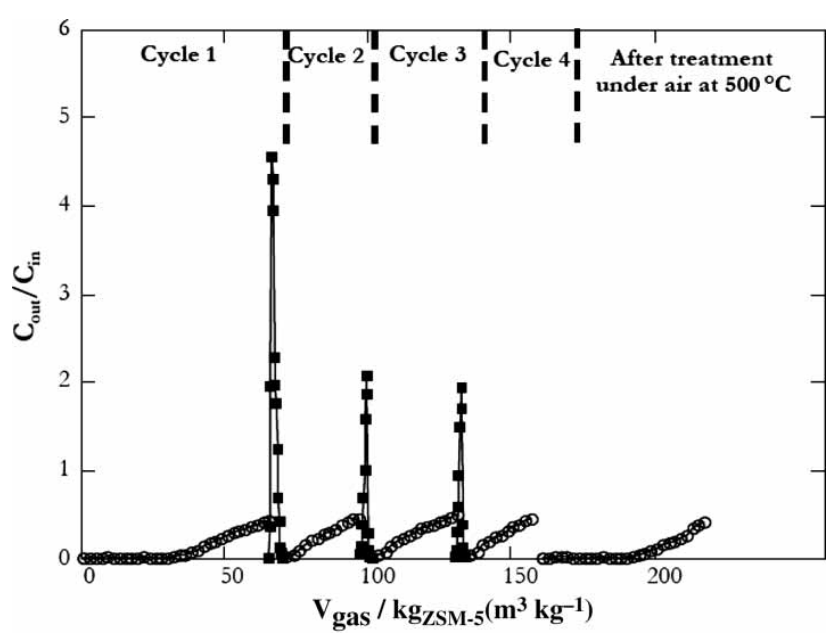

Figure $\mathbf{5}$ | Cyclic study of adsorption/ozonation of MEK on ZSM-5. O: adsorption of MEK $\left(1.35 \mathrm{~g} \mathrm{~m}^{-3}\right)$ on ZSM-5, $\mathbf{m}: \mathrm{O}_{3}$ on ZSM-5.

material, probably caused by some remaining adsorbed byproducts. A change in the physical or chemical surface of aluminosilicate is also possible (Valdes et al. 2010) and could be the origin of the decrease of adsorption.

The regeneration of adsorption capacity was estimated by comparing the adsorbed quantities of MEK on the two adsorbents before and after each ozonation. Results are reported in Figure 6.

Stabilization was observed after the first adsorption/ ozonation cycle, showing a constant regeneration rate. Fau-Y has better results than ZSM-5, with a constant regeneration rate of about $75-83 \%$. For ZSM-5, the regeneration rate is weaker $(28-32 \%)$ but the interesting point is that it is stable. Strong heating of the ZSM-5 $\left(500{ }^{\circ} \mathrm{C}\right)$, showed

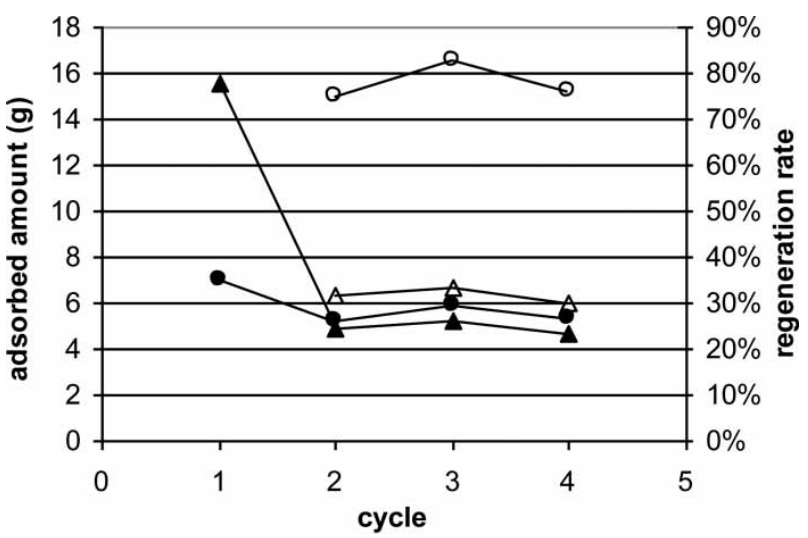

Figure 6 | Evolution of adsorption capacity during the adsorption/ozonation process. $\bullet$ : adsorbed amount on Fau-Y, $\mathbf{\Lambda}$ : adsorbed amount on ZSM-5; O: regeneration rate of Fau-Y, $\Delta$ : regeneration rate of ZSM-5.

that the adsorbed compounds could be desorbed. The readsorbed quantity of MEK was $14.3 \mathrm{~g}$, corresponding to 93\% of the adsorbed quantity at the first cycle of adsorption-ozonation for the ZSM-5. Thus, it can be deduced that no real irreversible poisoning of catalysts occurred during ozonation.

\section{CONCLUSIONS}

Experimental results of static adsorption and those conducted in the laboratory-scale pilot showed the feasibility of this treatment, coupling adsorption on microporous synthetic aluminosilicate and oxidation with ozone.

Good capture of MEK in dry or wet conditions was found and a good regeneration of the adsorbent occurred at ambient temperature and pressure, with better results for Fau-Y. The main products of oxidation were $\mathrm{CO}_{2}$ and $\mathrm{H}_{2} \mathrm{O}$. Intermediates of oxidation such as 2,3-butanedione and acetic acid were identified, leading to incomplete mineralization. The adsorbents' efficiency was not highly affected after four consecutive cycles of MEK adsorption-ozonation. These results show that the same sample of adsorbent can be used in the treatment process for a long time. Ozonation regeneration is a promising process for VOC removal.

\section{REFERENCES}

Alvarez, P. M., Beltran, F. J., Gomez-Serrano, V., Jaramillo, J. \& Rodriguez, E. M. 2004 Comparison between thermal and ozone regenerations of spent activated carbon exhausted with phenol. Water Res. 38, 2155-2165. 
Brosillon, S., Manero, M.-H. \& Foussard, J.-N. 200I Mass transfer in VOC adsorption on zeolite. Environ. Sci. Technol. 35, 3571-3575.

Einaga, H. \& Ogata, A. 2009 Benzene oxidation with ozone over supported manganese oxide catalysts: effect of catalyst support and reaction conditions. J. Haz. Mat. 164, 1236-1241.

Einaga, H., Teraoka, Y. \& Ogata, A. 2oIo Benzene oxidation with ozone over manganese oxide supported on zeolite catalysts. Catal. Today 164, 571-574.

Konova, P., Stoyanova, M., Naydenov, A., Christoskova, S. \& Mehandjiev, D. 2006 Catalytic oxidation of VOCs and CO by ozone over alumina supported cobalt oxide. Appl. Catal. A: General 298, 109-114.

Kwong, C. W., Chao, C. Y. H., Hui, K. S. \& Wan, M. P. 2008 Catalytic ozonation of toluene using zeolite and MCM-41 materials. Env. Sci. Technol. 42, 8504-8509.

Meininghaus, C. K. W. \& Prins, R. 2000 Sorption of volatile organic compounds on hydrophobic zeolites. Micropor. Mesopor. Mater. 35-36, 349-365.

Monneyron, P., Manero, M. -H. \& Foussard, J. -N. 2003 Measurement \& modelling of single \& multicomponent adsorption equilibria of VOC on high-silica zeolites. Env. Sci. Tech. 30, 2410-2418.
Monneyron, P., Manero, M.-H. \& Mathe, S. 2007 A combined selective adsorption and ozonation process for VOCS removal from air. Can. J. Chem. Eng. 85, 326-332.

Sagehashi, M., Shiraishi, K., Fujita, H., Fujii, T. \& Sakoda, A. 2005 Ozone decomposition of 2-methylisoborneol (MIB) in adsorption phase on high silica zeolites with preventing bromate formation. Water Res. 39, 2926-2934.

Sing, K. S. W., Everett, D. H., Havic, R. A. W., Moscou, L., Pierotti, R. A., Rouquerol, J. \& Siemieniewska, T. 1985 Reporting physisorption data for gas/solid systems with special reference to the determination of surface area and porosity. Pure Appl. Chem. 57, 603-619.

Valdes, H., Tardon, R. F. \& Zaror, C. A. 2009 Methylene blue removal from contaminated waters using $\mathrm{O}_{3}$, natural zeolite, and $\mathrm{O}_{3}$ /zeolite. Wat. Sci. Technol. 60, 1419-1424.

Valdes, H., Tardón, R. F. \& Zaror, C. A. 20Io Effect of zeolite chemical surface properties on catalytic ozonation of methylene blue. Ozone: Sci. Eng. 32, 344-348.

Wang, S., Li, H. \& Xu, L. 2006 Application of zeolite MCM22 for basic dye removal from wastewater. J. Colloid Interf. Sci. 295, 71-78.

Zhao, X. S., Ma, Q. \& Lu, G. Q. I998 VOC Removal: comparison of MCM-41 with hydrophobic zeolites and activated carbon. Energ. Fuel. 12, 1051-1054. 